\title{
Linking larval abundance, onshore supply and settlement using instantaneous versus integrated methods
}

\author{
S. E. Dudas ${ }^{1, *}$, G. Rilov ${ }^{1,2}$, J. Tyburczy ${ }^{1}$, B. A. Menge ${ }^{1}$ \\ ${ }^{1}$ Oregon State University, Department of Zoology, 3029 Cordley Hall, Corvallis, Oregon 97331, USA \\ ${ }^{2}$ Present address: National Institute of Oceanography, Israel Oceanographic and Limnological Research (IOLR), \\ PO Box 8030, Haifa, 31080, Israel
}

\begin{abstract}
Understanding larval transport mechanisms is important to coastal ecosystem dynamics. However, the relationships between nearshore larval abundance, onshore supply and settlement remain poorly understood. We investigated instantaneous versus integrated methods to quantify barnacle and mussel larval distributions as larvae traverse the last 100s of $\mathrm{m}$ of water, are delivered and eventually settle onshore. Using the shore's edge at low tide as a horizontal reference $(\sim 0 \mathrm{~m})$, we sampled at the following distances: >100s of $\mathrm{m}$ (offshore; Stn 1), >1 to $5 \mathrm{~m}$ (nearshore; Stn 2) and -10 to $-15 \mathrm{~m}$ (onshore; Stn 3). Offshore we used integrated collectors on moorings, nearshore instantaneous pump samples were taken and onshore integrated plankton traps and collectors were deployed. All sampling methods captured spatiotemporal variability but each sampled a different part of the water column and potentially, larval life history. As larvae moved across the shore, distributions varied by taxon, depth and sampling method. Offshore, mussel settlement varied between sites and depth. Nearshore, mussel and barnacle larval abundances were coherent between sites. Mussel larvae were well mixed vertically while barnacle larvae were stratified (higher abundances at $1 \mathrm{~m}$ ). Onshore (Stn 3) larval supply (traps) differed between sites for mussels only and settlement differed for barnacles. Temporal coherence was high for the settlement, larval abundance and onshore supply of mussels, as well as onshore barnacle settlement. Each sampling method was useful for examining larval distributions in a different part of the environment. Used in concert, these methods provide a powerful approach for linking oceanographic processes with nearshore larval abundance, onshore delivery and replenishment of benthic communities.
\end{abstract}

KEY WORDS: Invertebrate $\cdot$ Larval distribution $\cdot$ Larval supply $\cdot$ Intertidal settlement $\cdot$ Spatial and temporal variability $\cdot$ Transport $\cdot$ Mussel $\cdot$ Barnacle

Resale or republication not permitted without written consent of the publisher

\section{INTRODUCTION}

Determining the relationship between larval supply (delivery to the shore), settlement (larval attachment to the substratum) and recruitment (metamorphosis and survival to a certain size or age) to benthic communities has long been one of the most challenging problems facing marine ecologists, both intellectually and logistically (Underwood \& Denley 1984, Gaines \& Roughgarden 1985, Pineda 2000, Todd et al. 2006). From an intellectual standpoint, understanding the contribution of supply to patterns of distribution and abundance of populations and communities will go far in helping us to understand how ecosystems function. Pragmatically, understanding the nature of the linkage between larval supply, recruitment and adult population size would be a step forward in the management of fisheries and more generally in the development of strategies of ecosystem-based management (Leslie \& McLeod 2007). As a consequence, ecologists and fisheries biologists have spent decades tackling this issue. Progress has been slow, primarily due to 
the enormous practical difficulties in determining the processes underlying the transport, settlement and recruitment of propagules (e.g. Pineda 2000). Larvae and recruits are usually microscopic and live in an environment that is difficult to access, processes underlying their transport vary across many scales in space and time and both biological sampling and quantification technologies are usually the result of many compromises.

Here we report an effort to address some of these challenges utilizing a variety of sampling methods. Our focus is primarily on the scales of spatial and temporal coherency of intertidal barnacle and mussel larvae as they are transported shoreward and delivered to adult habitats. As our testbed, we use the rocky intertidal habitat and inner shelf waters through which the planktonic larvae of most intertidal organisms travel during their larval development and dispersal period. Our approach presumes that comparing abundances of larvae obtained using both instantaneous and integrated samples to simultaneous measurements of key oceanographic characteristics will provide insight into the oceanographic mechanisms that influence larval supply and the replenishment of onshore benthic communities. We believe that this is particularly important in upwelling regions where these oceanographic mechanisms (e.g. upwelling, downwelling) are likely to change in response to global warming (Bakun \& Weeks 2004, Vecchi et al. 2006). In the present study we address primarily the biological side of this comparison, focusing on larval distribution and settlement, as a precursor to our ongoing research which includes both biological and oceanographic measurements.

Determining the influence of larval availability and supply to intertidal communities requires a feasible, effective way of sampling offshore and nearshore larvae and onshore delivery. In high wave exposure environments, finding practical sampling methods is not a trivial task. Because research vessels cannot get close to the shore, traditional plankton sampling methods, such as net tows or pump samples, are limited to regions farther offshore and/or calm conditions. An additional difficulty is the spatial and temporal patchiness of larvae. Traditional plankton sampling methods typically involve temporally discrete, instantaneous samples that may inadequately assess larval abundance if temporal variation is high (Gaines \& Bertness 1993). These sample types (e.g. nets, pumps) that assess larval abundance can provide an index of larvae availability (i.e. larvae that are avail- able to be delivered onshore). The larvae measured in these samples may or may not be transported onshore and include both competent and precompetent larvae.

More recently, plankton traps have been developed to measure plankton abundance integrated over longer periods of time. Passive tube traps, similar in design to sediment traps, have been used to sample larvae on semi-exposed shores (Todd 2003), estuaries (Yund et al. 1991) and subtidally (Gaines \& Bertness 1993), and work well in low turbulence environments (Castilla \& Varas 1998). Filter-cup traps have also been designed and improved to sample the exposed rocky intertidal shores (Castilla \& Varas 1998, Castilla et al. 2001, Yan et al. 2004) and have proved fruitful in assessing temporal variations in larval supply. Trap sample designs provide integrated measures of larval abundance over the duration of their deployment. Filter-cup traps also provide an index of larval supply -incorporating both larval abundance and flowwhich provides information on the actual delivery to the rocky intertidal of nearshore larvae that may settle and recruit to adult populations. Larvae measured in these samples, like the instantaneous samples, include both competent and precompetent larvae. Although the larvae may be delivered to shore, they do not necessarily settle.

Small moorings have been developed to measure settlement (as a proxy for competent larval abundance and availability) in shallow environments within 100s of $\mathrm{m}$ from the shore (McCulloch \& Shanks 2003, Rilov et al. 2008). Settlement collectors can also be deployed onshore to measure, or provide an index of, competent larvae delivered to the intertidal.

Each of the sampling methods described above potentially targets different stages of the life cycle (precompetent, competent, larvae, settler) and environment (offshore, nearshore, onshore; see Table 1 for a breakdown of sample types, temporal scale and environments sampled). We investigated the use of several of these methods to sample larvae adjacent to, and

Table 1. Larval sample types, target life cycle stage, sampling time scale, method and environment sampled

\begin{tabular}{|c|c|c|c|c|}
\hline Sample type & Target & Time scale & Method & Environment \\
\hline Instantaneous & Larvae & Seconds-minutes & Pump & $\begin{array}{c}\text { Nearshore } \\
(1-5 \mathrm{~m})\end{array}$ \\
\hline \multirow[t]{2}{*}{ Integrated } & Larvae & Hours-days & Filter-cup traps & Onshore \\
\hline & $\begin{array}{c}\text { Competent } \\
\text { larvae/settlers }\end{array}$ & Hours-days & $\begin{array}{c}\text { Settlement } \\
\text { collectors }\end{array}$ & $\begin{array}{l}\text { Offshore } \\
\text { (100s of m), } \\
\text { onshore }\end{array}$ \\
\hline
\end{tabular}


directly from, the shore to which they are delivered. Determining the differences between each sample type is crucial for identifying the method appropriate and necessary for answering questions about larval dispersal and transport mechanisms. To the best of our knowledge, this is the first time a direct comparison of all of these sampling methods has been made simultaneously over these scales.

The overall goal of the present study was to investigate local-scale (10s to $100 \mathrm{~s}$ of $\mathrm{m}$ ) along-shore and across-shore spatiotemporal variability in larval abundance that occurs across the last 100s of m larvae traverse as they approach, and are delivered to, the shore. Specifically, we wanted to determine if larval abundances and settlement were both spatially and temporally coherent at scales of $10 \mathrm{~s}$ to $100 \mathrm{~s}$ of $\mathrm{m}$ over a time period of days. We employed a high-frequency sampling scheme to more closely match the temporal scale of the physical transport processes influencing larval delivery and settlement. We utilized several different sampling methods capturing all environments that larvae experience as they move shoreward to determine (1) the daily variability of barnacle and mussel larval abundance, onshore delivery and settlement at scales of $100 \mathrm{~s}$ of $\mathrm{m}$ along-shore, across-shore and with depth within the upper $5 \mathrm{~m}$ of the water column; and (2) the timing of onshore larval delivery and settlement at these scales. We then compared these findings to establish if different sampling methods (integrated and instantaneous) yielded similar results.

We made 5 predictions: (1) in waters adjacent to shore, instantaneous estimates of daily larval abundance, and potentially, integrated onshore supply, should be similar at scales of $100 \mathrm{~s}$ of $\mathrm{m}$ because the oceanographic mechanisms delivering the larvae to the shore are likely similar; (2) onshore settlement will vary along-shore at scales of 100s of m (between-sites) because of local-scale substratum-related differences (e.g. flow over the substratum, chemical cues); (3) timing of onshore larval delivery and settlement pulses will be similar due to coherent oceanographic influences on larval delivery; (4) taxon-related differences in settlement will occur because of differential larval behaviour in barnacles and mussels (i.e. differences in vertical depth distributions); and (5) because the different sampling methods likely sample different environments and/or life cycle stages, each method will yield different results, with abundances from those employing the integrated methods (i.e. larval traps and settlement collectors) being more similar.

\section{MATERIALS AND METHODS}

Study sites. The present study was conducted at Fo-

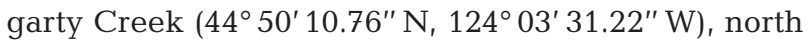
of Depoe Bay, Oregon, USA, from 17 to 27 August 2005 (Fig. 1A). Fogarty Creek was chosen as the study location because it is close enough to the harbour to allow our research vessel to service moorings offshore. This location also has a large, relatively continuous rocky intertidal area enabling us to have 2 sites, approximately $160 \mathrm{~m}$ apart, at the north and south ends of the
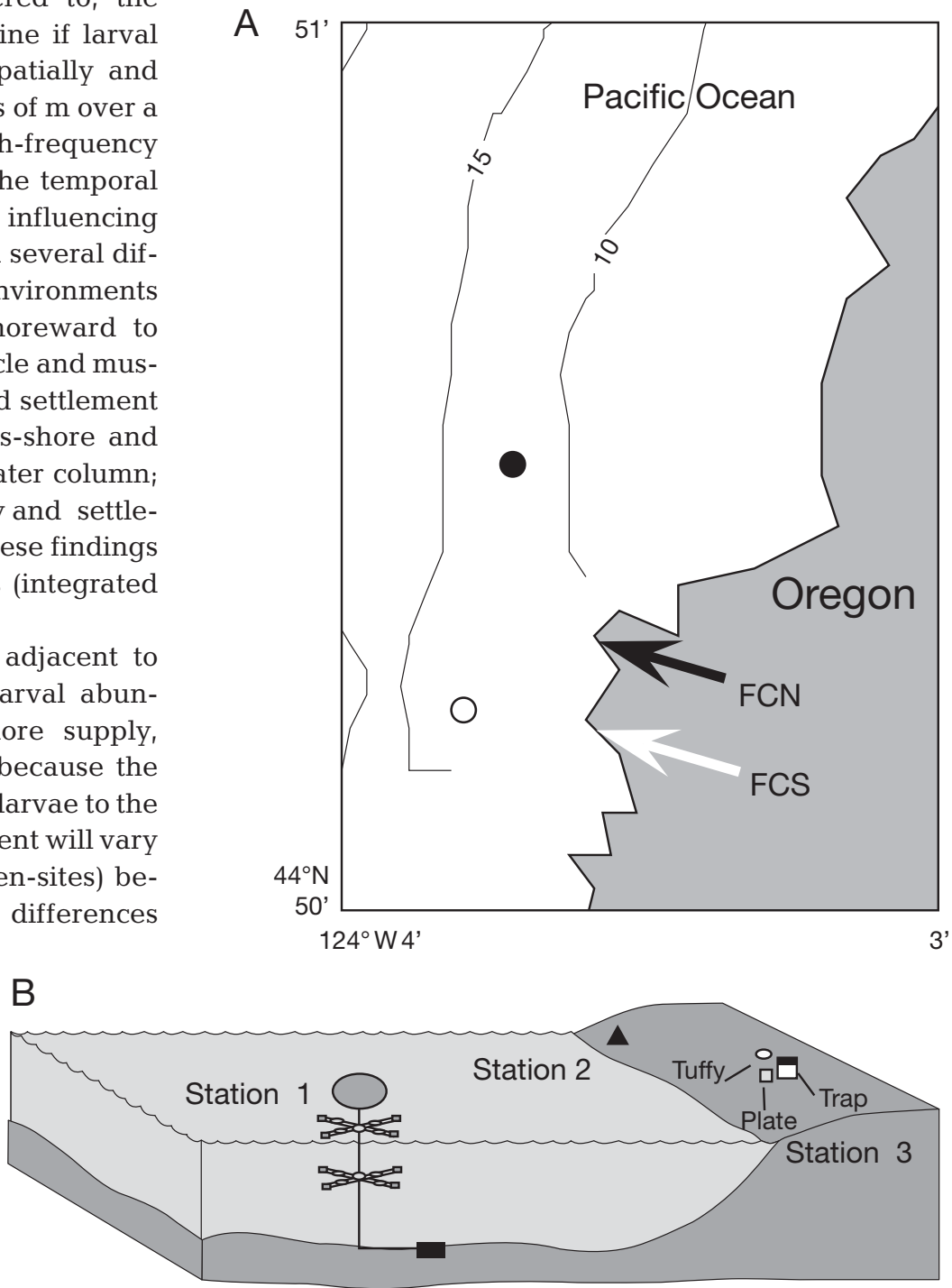

Fig. 1. Fogarty Creek (FC) study area. (A) Offshore mooring stations are marked at the North and South sites with filled and empty circles (Stn 1). Arrows point to onshore stations: black denotes north site (FCN), white denotes south site (FCS). Isobaths = depth (m). (B) Sampling schematic. Stn 1: offshore moorings with settlement collectors (plates and tuffies; Stn 2: pumping site adjacent to intertidal; and Stn 3: onshore larval traps and settlement collectors (plates collect barnacles, tuffies collect mussels). Not drawn to scale. Two sites located $160 \mathrm{~m}$ apart (each with the 3 stations) were sampled 
rocky intertidal bench. Each site had 3 stations as described below. These 3 stations were oriented acrossshore to measure larval and settler distributions just outside of the surf zone (offshore), within the surf zone (nearshore) and within the intertidal (onshore).

The following methods are organized from offshore to onshore to reflect the direction that larvae are expected to move as they are transported onshore. Using the edge of the intertidal at low tide as our reference (= $0 \mathrm{~m}$ along a horizontal, across-shelf axis), we defined 3 stations: Stn 1, offshore, was $\sim 350$ to 500 m offshore where sampling involved moorings with settlement collectors; Stn 2, nearshore, was 1 to $5 \mathrm{~m}$ seaward from the shore where sampling involved pumping water directly from shore; and Stn 3, onshore, was 10 to $15 \mathrm{~m}$ landward from the low tide waterline where sampling involved larval traps and settlement collectors placed in the intertidal (Fig. 1B). Barnacles and mussels were chosen as the focal organisms in the present study as they are dominant space occupiers, important prey in the intertidal food web and habitatforming species in this system.

Stn 1: offshore settlement. Offshore moorings were constructed with PVC frames attached to a mooring line with an anchor at one end and a float at the other (Fig. 1B). Barnacle and mussel settlement were measured using settlement collectors intended to mimic natural substrates (i.e. rock and filamentous algae), while offering more consistent uniformity than natural surfaces (e.g. Farrell et al. 1991, Menge et al. 1994). For barnacles, we used PVC plates covered by a rugose surface (Safety-Walk ${ }^{\mathrm{TM}}$, 3M; Farrell et al. 1991). For mussels, we used SOS tuffy pads (Clorox) to provide a filamentous plastic matrix (Menge et al. 1994). Settlement collectors (i.e. plates and tuffies) were bolted to the arms of the frame with 5 plates and tuffies per frame and deployed at 1 and $5 \mathrm{~m}$ depths. Settlement was used as a proxy for nearshore abundance of competent larvae. We also deployed chalk blocks (Die-keen dental chalk; 2 per frame) to provide a rough estimate of water flow. Chalk or gypsum blocks have been used in many studies (Yund et al. 1991, Hunt \& Scheibling 1996, Guichard \& Bourget 1998) to provide a proxy for flow, although recent studies have highlighted some limitations (see 'Material and methods: Stn 3: onshore integrated larval sampling'). Moorings were deployed as close to shore as logistically possible: approximately $500 \mathrm{~m}$ directly off the north site and $350 \mathrm{~m}$ off the south site in water 10 to $15 \mathrm{~m}$ deep. Settlement collectors and chalk blocks were exchanged daily from 17 to $23 \mathrm{Au}-$ gust with the exception of 22 August when sea conditions were too rough.

Stn 2: nearshore instantaneous larval sampling. To determine plankton larval abundances, instantaneous plankton pump samples were taken daily during the lower low tide adjacent to the intertidal, directly from the shore's edge using a Honda WX15 gasoline-powered water pump. At the south site the rocky bench has a sheer vertical drop which enabled pumping at 2 depths: near-surface $(\sim 1 \mathrm{~m})$ and near-bottom $(\sim 5 \mathrm{~m})$. The topography at the north site only allowed sampling from the near-surface $(1 \mathrm{~m})$. Water was filtered through a $64 \mu \mathrm{m}$ mesh net and samples were preserved in $95 \%$ ethanol. Approximately 1501 of water were pumped per sample, and triplicate samples were pumped each day per site (and per depth for the south site).

Stn 3: onshore integrated larval sampling. Integrated onshore larval supply was measured using plankton traps modified from the designs of Castilla \& Varas (1998), Castilla et al. (2001) and Yan et al. (2004). The traps collect larvae from the water as it flows over the rocky intertidal benches, and measure the abundance of larvae supplied and/or delivered to the intertidal. The traps consist of a $10 \mathrm{~cm}$ length of $10 \mathrm{~cm}$ diameter PVC pipe with a PVC end cap secured to the rock with stainless steel brackets and lag screws (Fig. 2). Larvae entered the trap via a $10 \mathrm{~cm}$ plastic funnel fitted with a $1 \mathrm{~cm}$ 1 -way ball valve and were retained in a $100 \mu \mathrm{m}$ mesh net which was nested inside the PVC body. The net and funnel were secured inside the PVC body with a rubber ring and pipe clamp. Nets were soaked in $4 \%$ formalin prior to deployment to ensure that organisms would be killed upon entry (Yan et al. 2004). Five replicate traps were deployed at each site within the mid-intertidal zone in areas as similar as logistically possible. Nets were changed daily during the lowest low tide. Upon removal nets were soaked in $95 \%$ ethanol and taken back to the

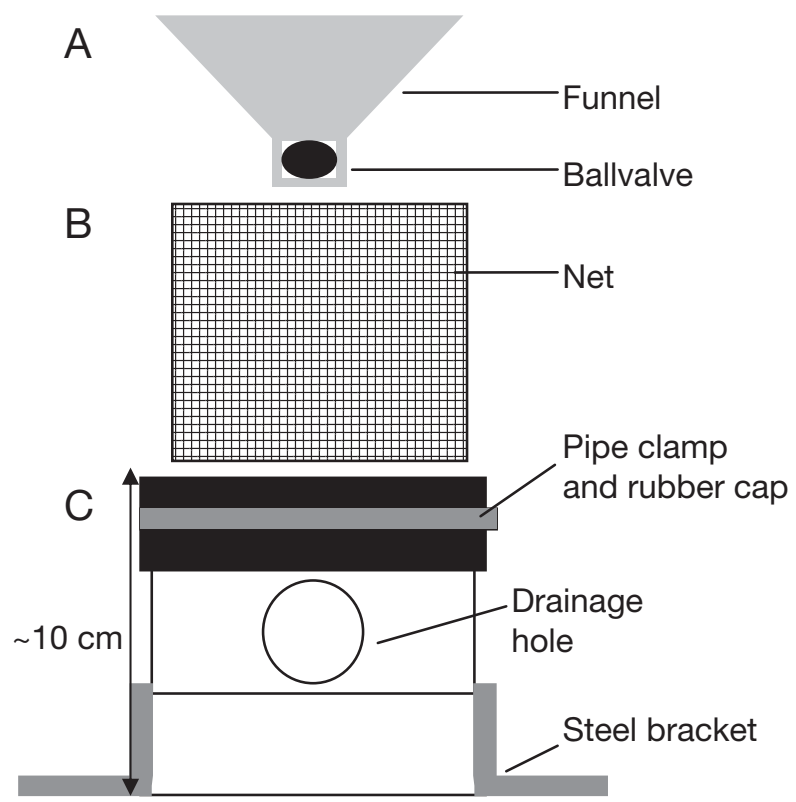

Fig. 2. Schematic of onshore larval trap. (A) funnel with 1-way $1 \mathrm{~cm}$ ball valve, (B) net and (C) trap body 
laboratory where the plankton were rinsed out of the net and stored in $95 \%$ ethanol.

Stn 3: onshore settlement. Barnacle and mussel settlement abundances were measured with settlement collectors (i.e. plates and tuffies). Five replicates were deployed onshore at each site alongside the plankton traps. Chalk blocks were also deployed with each of the 5 replicates to provide an estimate of flow in each replicate. We are aware that this method has limitations. Porter et al. (2000) showed that chalk dissolution rates vary in different flow environments (e.g. steady, fluctuating, mixed flow) and consequently suggested caution in using this technique as an index of integrative water motion. Chalk dissolution provides an estimate of mass-transfer which will be influenced by the amount, type and variability of flow, temperature, salinity and turbulence. However, currently there are no inexpensive alternative instruments that can measure flow in this kind of shallow, high wave-exposure environment. Therefore the chalk blocks provide only a crude estimate of water flow and we interpret our results conservatively (Porter et al. 2000).

Two caveats are necessary. First, we recognize that to achieve a truly balanced design, it would have been optimal to have pumped at Stns 1 and 3 and have had collectors at Stn 2. However, placing collectors in the shallow subtidal was logistically unfeasible due to high turbulence at the edge of this wave-beaten reef. Similarly, logistical and aesthetic concerns at this site prevented placement of an intertidal pumping system. Although our design is not orthogonal, we believe that our compromised approach provided useful insights into the strengths and weaknesses of instantaneous and integrated approaches of larval sampling. Second, an ideal study would have included at least one more intensive $7 \mathrm{~d}$ campaign such as this, but logistical constraints prevented a repeat in 2005 . The present study is thus the first step in a series of ongoing investigations of larval transport using high frequency sampling (S. E. Dudas et al. unpubl. data).

Onshore water properties. Onshore (Stn 3) sea surface temperature and salinity were measured using a YSI multiprobe system. Bucket surface water samples were taken to measure chlorophyll a (chl $a$; as a proxy for phytoplankton abundance), which was extracted following the methods of Welschmeyer (1994). Briefly, water samples were filtered onto $0.70 \mu \mathrm{m}$ glass fibre filters and then chl a was extracted from the filter by submersing in $90 \%$ acetone for approximately $24 \mathrm{~h}$, after which fluorescence was measured. Fluorescence was converted to chl a using the non-acidification method of Welschmeyer (1994).

Sample processing. Mussels Mytilus spp. and barnacle cyprids Balanus glandula, B. crenatus, B. nubilus, Chthamalus dalli and Pollicipes polymerus were enu- merated for whole-trap plankton samples. Only barnacle cyprids could be identified to species. Although mussels could not be identified to species, it appears from the juvenile mussels observed onshore over winter, following fall settlement, that most settling mussels are likely M. trossulus (B. A. Menge unpubl. data). Only mussels large enough to be potential settlers (i.e. competent larvae, $>230 \mu \mathrm{m}$ ) were used in the analyses. The concentration of larvae in pump samples was extremely dense, so subsamples were counted with a minimum of $25 \%$ of the sample or 100 individuals of each of the target species (i.e. mussels and barnacles). Subsamples were taken by agitating the sample to equally distribute plankton and then removing 10 or $20 \mathrm{ml}$ aliquots with a Hensen-Stempel pipette. Samples were counted manually using a dissecting microscope.

All mussels collected on tuffies were enumerated and all barnacle cyprids and metamorphs collected on plates were enumerated and identified to species.

Statistics. Larval and settlement distributions were analyzed using 2-way ANOVA with date and site or depth as fixed factors. When necessary, data were logtransformed $(\ln [x+1])$ to meet the assumptions of normality and homogeneity of variance. In some cases transformation did not achieve normality but the p-values were usually small enough that the analysis is likely to be robust to this violation (Underwood 1997). Cases where transformation did not achieve normality are noted in Table legends. For the instantaneous pump samples we condensed our time series to omit all dates with missing samples to allow for the calculation of the interaction between date and site. One-way ANOVAs were used to test for between-site differences in salinity and temperature. Two-way ANOVAs were used to test the effects of date and site, date and depth, and date and chl a. Dissolution rates of the chalk blocks were compared between sites and depths with 2-way ANOVAs with either date and site or date and depth as fixed factors. Kendall's $\tau$ was used to determine the relationship between larval traps, pump samples, settlement collectors and physical variables at both sites. Prior to correlation analysis all data sets were examined for autocorrelation. Level of significance in all tests was $\mathrm{p}=0.05$.

\section{RESULTS}

Results are organized into subsections based on the variability presented: along-shore, across-shore, vertical (depth), temporal, sample type and environmental variables. Within the subsections, results are organized by the expected direction of larval movement from offshore to nearshore to onshore (as in 'Materials and methods'). 


\section{Along-shore variability}

Overall, settlement densities routinely varied on a daily basis (date was almost always significant as a main effect or interacting with site) (Figs. $3 \& 4$, Table 2). Variation in space (between sites) also occurred, but less consistently, the settlement and larval distributions often being coherent at scales of 100s of m. For barnacles, larval species or settler composition changed abruptly moving from nearshore (Stn 2, instantaneous pump samples) to mid-intertidal surfaces (Stn 3, integrated trap samples).

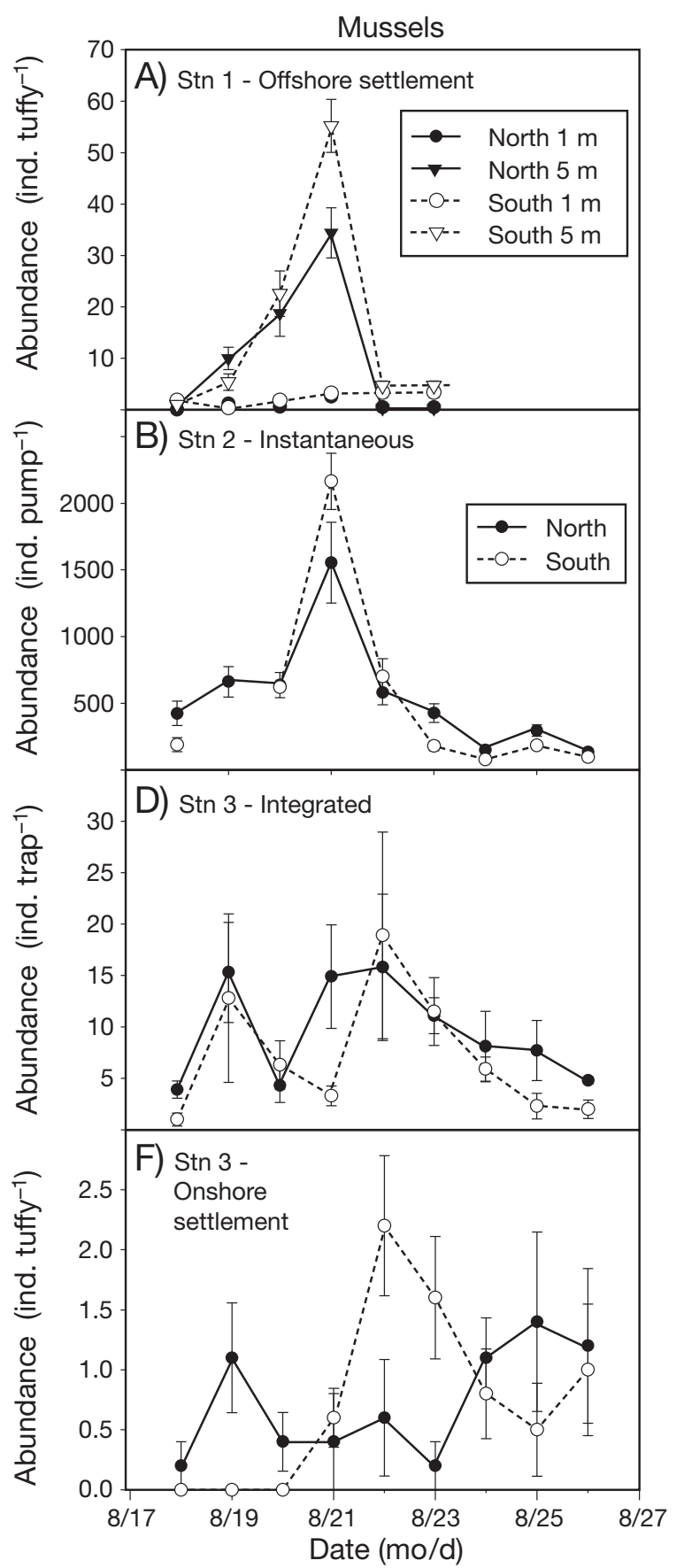

No barnacle settlement was observed at Stn 1. Almost no onshore settlement was observed for any of the 4 species delivered to the intertidal except for Balanus glandula (Fig. 4). Details follow.

\section{Stn 1: offshore settlement}

Mussel settlement at $5 \mathrm{~m}$ varied with date and was greater at the south site (Date $\times$ Site interaction) (Table 2, Fig. 3A)

Fig. 3. Time series of mean Mytilus spp. mussels (left panel) and total barnacle cyprids (right panel) at (A) Stn 1, (B,C) Stn 2, (D,E) Stn 3, integrated onshore trap samples and $(F, G)$ Stn 3 , onshore settlement collectors. Total barnacles include Balanus crenatus, B. glandula, B. nubilus, Chthamalus dalli and Pollicipes polymerus. Error bars \pm SE. Note the $y$-axis scale varies between panels

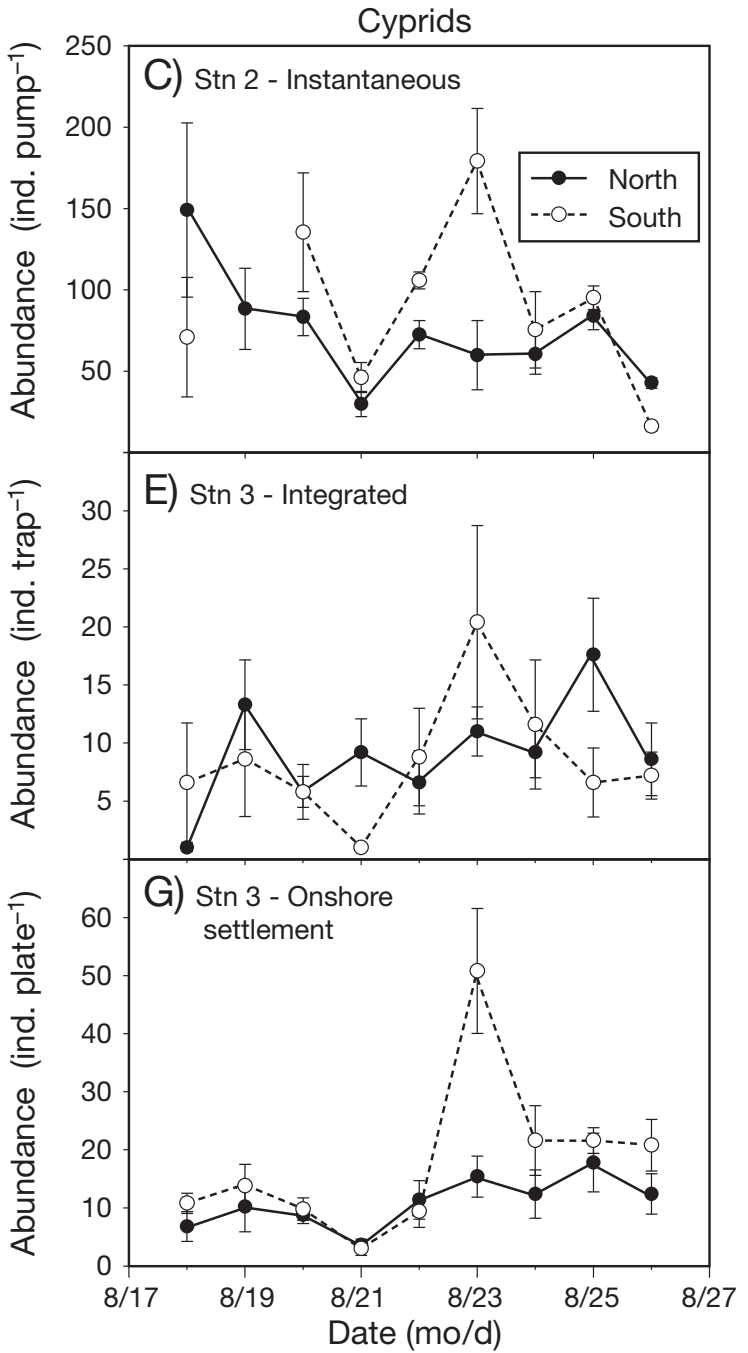



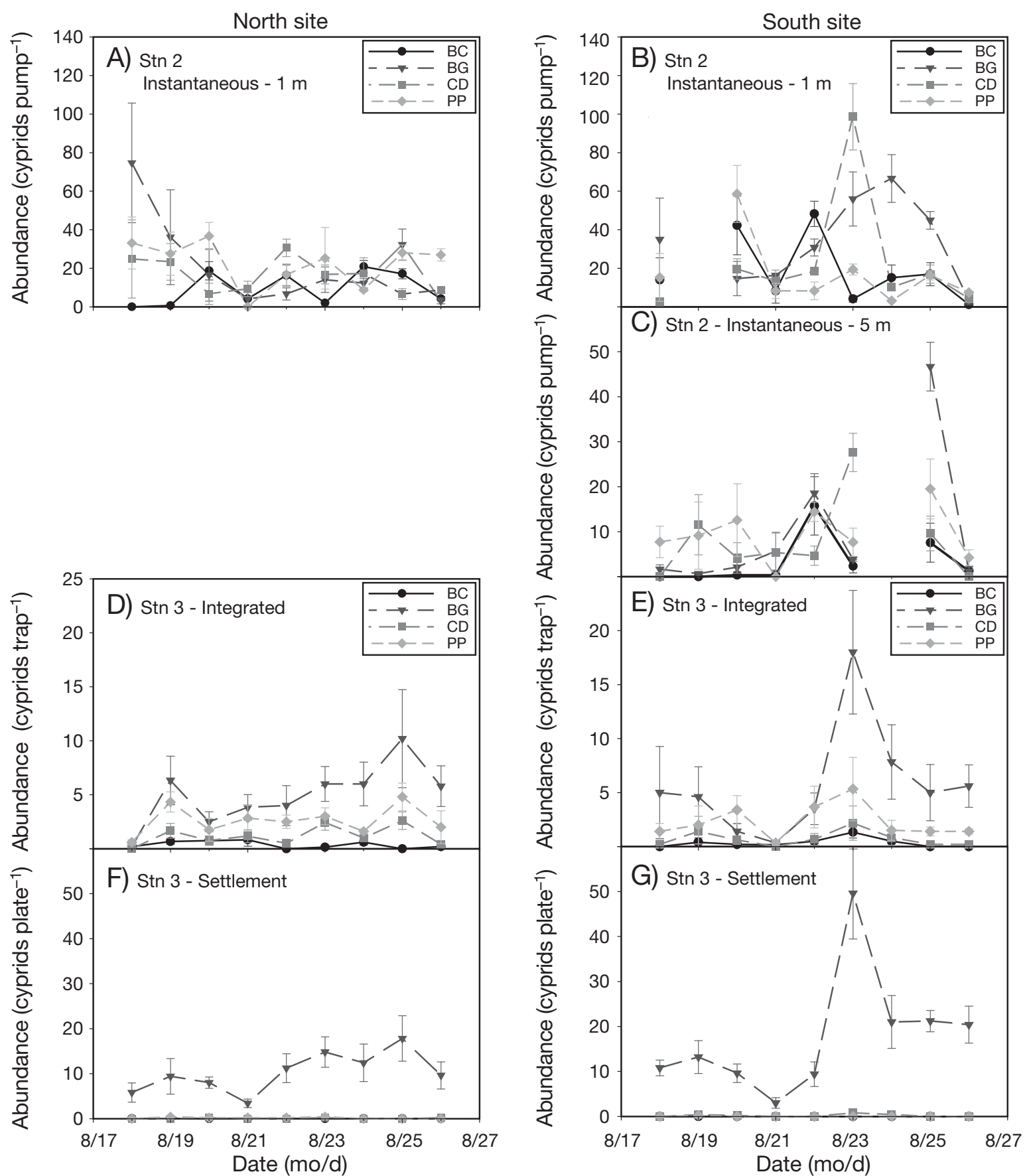

Fig. 4. Mean barnacle species abundance from Stn 2 (A-C) instantaneous (1 and $5 \mathrm{~m}$ for south site) and Stn 3 (D,E) integrated and $(\mathrm{F}, \mathrm{G})$ onshore settlement samples for north and south sites. BC: Balanus crenatus, BG: B. glandula, CD: Chthamalus dalli, PP: Pollicipes polymerus. Error bars: \pm SE

Stn 2: nearshore instantaneous larval samples

Closer to shore, mussel larvae and barnacle cyprid abundances at $1 \mathrm{~m}$ depth also varied over time (mussels: $F_{7,32}=43.0, \mathrm{p}<0.001$; barnacles: $F_{7,32}=3.00$, $\mathrm{p}=0.02$ ) but not between sites (Fig. 3B,C), suggesting distributions were spatially coherent. Abundances of all barnacle species varied over time with the exception of Balanus nubilus. Abundances of B. glandula and Chthamalus dalli varied in space and time (Date $\times$ Site, B. glandula: $F_{7,22}=3.22, \mathrm{p}=0.02, C$. dalli: $F_{7,22}=$ 3.32, $\mathrm{p}=0.01$ ) (Fig. 4A-C). Barnacle species composi- 
Table 2. Two-way ANOVA results for (A) Stn 1, offshore mussel settlement at $5 \mathrm{~m}$, (B) Stn 3, integrated onshore mussel supply and (C) Stn 3, onshore barnacle settlement. Date and Site are fixed factors. ${ }^{\mathrm{a}}$ : non-normal data

\begin{tabular}{|c|c|c|c|c|c|}
\hline Source & SS & df & MS & $F$ & $\mathrm{p}$ \\
\hline \multicolumn{6}{|c|}{ Stn 1-Offshore mussel settlement, $5 \mathrm{~m}, \mathrm{r}^{2}=0.91$} \\
\hline Date & 114 & 4 & 28.5 & 95.5 & $<0.001$ \\
\hline Site & 3.29 & 1 & 3.29 & 11.0 & $<0.001$ \\
\hline Date $\times$ Site & 6.29 & 4 & 1.57 & 5.27 & $<0.001$ \\
\hline Error & 11.9 & 40 & 0.30 & & \\
\hline \multicolumn{6}{|c|}{ Stn 3-Integrated onshore mussel supply ${ }^{\mathrm{a}}, \mathrm{r}^{2}=0.40$} \\
\hline Date & 21.6 & 8 & 2.69 & 3.31 & $<0.001$ \\
\hline Site & 4.84 & 1 & 4.85 & 5.96 & 0.02 \\
\hline Date $\times$ Site & 9.01 & 8 & 1.13 & 1.39 & 0.22 \\
\hline Error & 52.6 & 64 & 0.81 & & \\
\hline \multicolumn{6}{|c|}{ Stn 3-Onshore barnacle settlement, $\mathrm{r}^{2}=0.59$} \\
\hline Date & 37.0 & 8 & 4.62 & 9.47 & $<0.001$ \\
\hline Site & 6.12 & 1 & 6.12 & 12.5 & $<0.001$ \\
\hline Date $\times$ Site & 7.28 & 8 & 0.91 & 1.89 & 0.79 \\
\hline Error & 35.1 & 72 & 0.49 & & \\
\hline
\end{tabular}

tion was also variable, with no single species dominating abundances (Fig. 4A-C).

Stn 3: onshore integrated larval samples

Onshore mussel larval supply was greater at the north site and varied over time (Table 2, Fig. 3D). Onshore larval cyprid supply was spatially coherent. There were no differences in onshore larval cyprid supply for the 2 species observed in large enough numbers for analysis, Pollicipes polymerus and Balanus glandula, between sites (data not shown) and only B. glandula varied over time $\left(F_{8,1}=3.53, \mathrm{p}=0.002\right)$ (Figs. 3E \& 4D,E).

\section{Stn 3: onshore settlement collectors}

Onshore cyprid settlement was higher at the south site and varied over time (Table 2, Fig. 3G). Balanus glandula was the dominant barnacle species on onshore plates (and in the traps, Fig. 4D-G). Chthamalus dalli and Pollicipes polymerus were the only others to settle, but comprised only $0.1 \%$ of the total settlers observed. Onshore mussel settlement was very low and was therefore excluded from statistical analysis (Fig. 3F).

\section{Across-shore variability}

Correlations between the offshore and onshore environment were limited to mussels due to lack of offshore barnacle settlement on mooring plates. At neither site were abundances of settlers and larvae correlated across-shore among stations (Table 3). At the south site, abundances of mussel larvae at Stn 2 were correlated between depths (Table 3).

\section{Depth variability}

Depth distributions differed by proximity to shore and taxa. Only mussel depth distributions were observed at Stn 1.

\section{Stn 1: offshore settlement}

Offshore mussel settlement at both north and south sites varied with time and depth in the water column (Date $\times$ Depth interaction for mussels) (Table 4, Fig. 3A). At both sites settlement was higher at $5 \mathrm{~m}$ depth compared to $1 \mathrm{~m}$. These findings suggest that mussel settlement distributions are not spatially coherent with depth.

\section{Stn 2: nearshore instantaneous larval samples}

Cyprid abundance at the south site was greater at $1 \mathrm{~m}$ depth and varied between dates (Table 4, Fig. 5A). Balanus glandula and Chthamalus dalli had greater abundances at $1 \mathrm{~m}$ depth (B. glandula: $F_{6,28}=5.26, \mathrm{p}=0.002$;

Table 3. Kendall's $\tau$ correlations between settlement at Stn 1 on mooring tuffies (MT: 5 m, settlement at 1 m was too low for analysis), mussel larvae caught at Stn 2 in instantaneous pump samples (1 and $5 \mathrm{~m}$ ) and Stn 3 onshore traps. Statistically significant correlations are in bold

\begin{tabular}{|c|c|c|c|c|c|}
\hline \multirow[t]{2}{*}{ Site-sample type } & \multicolumn{2}{|c|}{ North } & \multirow[b]{2}{*}{ Stn 3 -Trap } & -South - & \multirow[b]{2}{*}{ Stn 2-Pump: $5 \mathrm{~m}$} \\
\hline & Stn 3-Trap & Stn 2-Pump: $1 \mathrm{~m}$ & & Stn 2-Pump: $1 \mathrm{~m}$ & \\
\hline Stn 1-MT: $5 \mathrm{~m}$ & -0.200 & 0.600 & -0.200 & 0.667 & 0.400 \\
\hline Stn 2-Pump: $1 \mathrm{~m}$ & 0.333 & 1.00 & 0.143 & 1.00 & - \\
\hline Stn 2-Pump: $5 \mathrm{~m}$ & - & - & 0.333 & 0.786 & 1.00 \\
\hline
\end{tabular}


Table 4. Two-way ANOVA results for Stn 1, offshore mussel settlement at the north site and Stn 2, nearshore barnacle larval abundance at the south site. Date and depth are fixed factors. ${ }^{a}$ : non-normal data

\begin{tabular}{|lccccc|}
\hline Source & SS & df & MS & $F$ & $p$ \\
\hline \multicolumn{5}{l}{ Stn 1-Offshore mussel settlement, north site } \\
Date & 45.8 & 4 & 11.5 & 36.8 & $<0.001$ \\
Depth & 25.3 & 1 & 25.3 & 81.2 & $<0.001$ \\
Date $\times$ Depth & 19.0 & 4 & 4.74 & 15.2 & $<0.001$ \\
Error & 12.5 & 40 & 0.31 & & \\
\multicolumn{5}{l}{} \\
Stn 2-Barnacle larval abundance, south site & \\
Date & 199 & 6 & 33.19 & 5.39 & $<0.001$ \\
Depth & 227 & 1 & 227 & 36.8 & $<0.001$ \\
Date $\times$ Depth & 56.0 & 6 & 9.34 & 1.52 & 0.21 \\
Error & 173 & 28 & 6.16 & & \\
\hline
\end{tabular}

C. dalli: $\left.F_{6,28}=5.60, \mathrm{p}=0.007\right)$ and varied between dates (B. glandula: $F_{1,28}=16.47, \mathrm{p}=0.001 ;$ C. dalli: $F_{1,28}=5.85$, $\mathrm{p}=0.03)$. B. crenatus and Pollicipes polymerus showed no differences or interactions between depth and date (Fig. 4B,C; statistical data for both species not shown). Mussel larval abundance varied over time $\left(F_{6,28}=55.4\right.$, p < 0.001) but not depth (Fig. 5B).

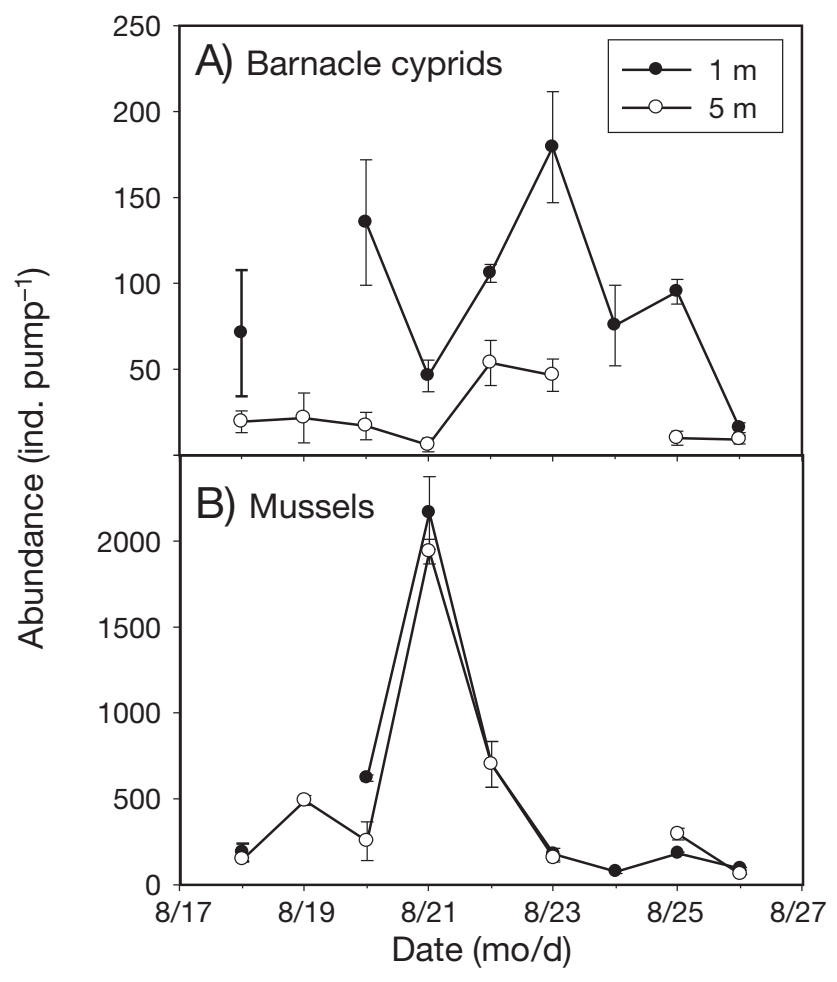

Fig. 5. Time series of mean larval abundance at Stn 2, per pump sample at 1 and $5 \mathrm{~m}$ depths for (A) all barnacle cyprids and (B) Mytilus spp. mussels at the south site. Error bars: $\pm \mathrm{SE}$

\section{Timing of offshore settlement and onshore larval delivery and settlement}

Between sites, Stn 1 mussel settlement at 5 m, Stn 2 mussel larval abundance and Stn 3 mussel larval supply were all positively correlated (Table 5, Fig. 3A,B,D), suggesting that their abundances are temporally coherent. Settlement of barnacles at Stn 1 and of mussles at $1 \mathrm{~m}$ depth at Stns 1 and 3 were insufficient for statistical analysis. Abundances of larval cyprids at Stns 2 and 3 were uncorrelated, but settlement on plates was positively correlated between sites (Table 5, Fig. 3C,E,G).

\section{Correlation between sample types}

In general, different types of integrated samples (i.e. settlement and onshore traps) were more positively correlated with each other than were integrated samples with instantaneous samples (i.e. settlement and/or traps versus pump samples). Stn 1 (integrated offshore) mussel settlement at $5 \mathrm{~m}$ was positively but non-significantly correlated with Stn 2 (nearshore instantaneous) mussel larval abundances, but not with Stn 3 (integrated onshore larval supply) (Table 3). Stn 2 nearshore integrated cyprid larval abundance and Stn 3 onshore integrated cyprid larval supply at the south site, and Stns 2 and 3 mussel abundance at both sites were also positively but non-significantly correlated (Table 6). At both sites, Stn 3 onshore integrated, cyprid abundance was positively correlated with Stn 3 settlement (Table 6). Settlement in onshore tuffies was too low for statistical analysis.

\section{Physical parameter analysis}

With the exception of flow at Stn 3, environmental patterns (chl $a$, salinity and temperature) tended to vary in parallel between sites (Figs. 6 \& 7, Table 7). Stn 1 chalk block dissolution varied over time and at the south site

Table 5. Kendall's $\tau$ correlations between barnacle cyprids and mussels at Stn 1 (mooring tuffies), Stn 2 (pumps) and Stn 3 (onshore plates and traps) between north (N) and south (S) sites. No. of mussel lavae settled on tuffies at Stn 1 at $1 \mathrm{~m}$ and at Stn 3 were too low for statistical analysis. No barnacle cyprids were found on plates at Stn 1. Statistically significant correlations are in bold

\begin{tabular}{|lcc|}
\hline Species & Sample & N-S correlation \\
\hline Mussels & Stn 1-Tuffies, 5 m & $\mathbf{0 . 8 6 7}$ \\
& Stn 2-Pump & $\mathbf{0 . 7 7 8}$ \\
Cyprids & Stn 3-Trap & $\mathbf{0 . 6 6 7}$ \\
& Stn 2-Pump & 0.056 \\
& Stn 3-Trap & 0.171 \\
& Stn 3-Plate & $\mathbf{0 . 6 8 6}$ \\
\hline
\end{tabular}


Table 6. Kendall's $\tau$ correlations between sample types at Stn 2, instantaneous larvae adjacent to shore (pump), and Stn 3 , integrated nearshore larvae (trap) and collectors (settlement plates and tuffies), for barnacle cyprid and mussel abundances. Statistically significant correlations are in bold

\begin{tabular}{|c|c|c|c|c|c|}
\hline & $\begin{array}{c}\text { Site and } \\
\text { sample type }\end{array}$ & \multicolumn{2}{|c|}{$\begin{array}{l}- \text { North }- \\
\text { Stn } 2-\operatorname{Stn} 3-\end{array}$} & \multicolumn{2}{|c|}{$\begin{array}{l}- \text { South }- \\
\text { Stn } 2-\text { Stn } 3-\end{array}$} \\
\hline Cyprids & $\begin{array}{l}\text { Stn 2-Pump } \\
\text { Stn 3-Plate }\end{array}$ & $\begin{array}{c}- \\
-0.141\end{array}$ & $\begin{array}{r}-0.141 \\
\mathbf{0 . 5 1 4}\end{array}$ & $\begin{array}{c}- \\
0.254\end{array}$ & $\begin{array}{l}0.254 \\
\mathbf{0 . 5 1 4}\end{array}$ \\
\hline Mussels & Stn 2 -Pump & - & 0.333 & - & 0.143 \\
\hline
\end{tabular}

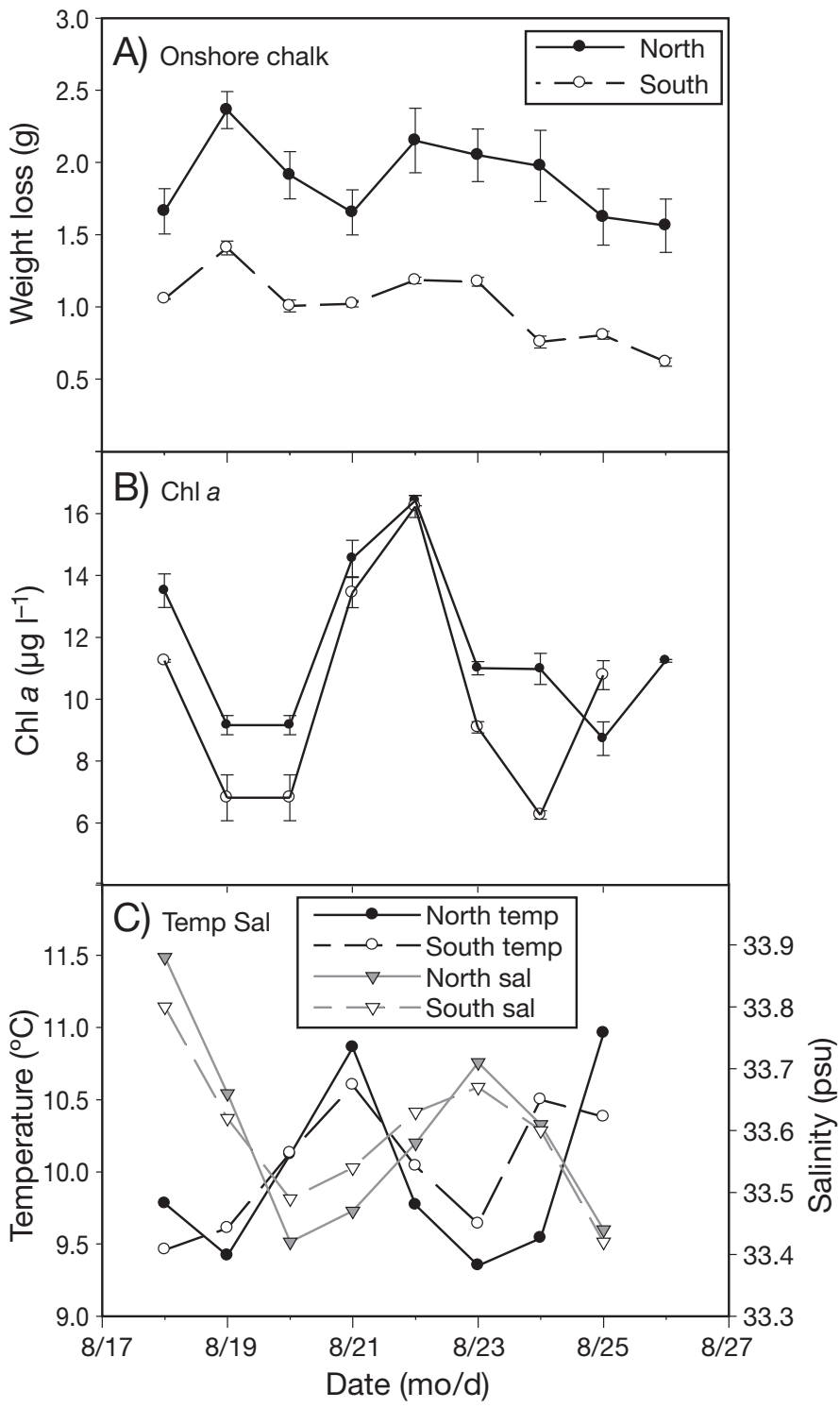

Fig. 6. Time series of mean (A) Stn 3 onshore chalk weight loss (as an estimate of water flow) (B) chlorophyll a (chl a) and $(\mathrm{C})$ temperature and salinity for north and south sites. Error bars: $\pm \mathrm{SE}$
Table 7. Kendall's $\tau$ correlations between north (N) and south (S) sites for chalk dissolution (proxy for flow) onshore and on moorings, temperature, salinity and chlorophyll a. Statistically significant correlations are in bold

\begin{tabular}{|lc|}
\hline Variable & N-S correlation \\
\hline Mooring chalk: $1 \mathrm{~m}$ & $\mathbf{0 . 8 0 0}$ \\
Mooring chalk: $5 \mathrm{~m}$ & $\mathbf{1 . 0 0}$ \\
Onshore chalk & $\mathbf{0 . 6 6 7}$ \\
Temperature & 0.357 \\
Salinity & $\mathbf{0 . 7 8 6}$ \\
Chlorophyll a & $\mathbf{0 . 6 1 9}$ \\
\hline
\end{tabular}

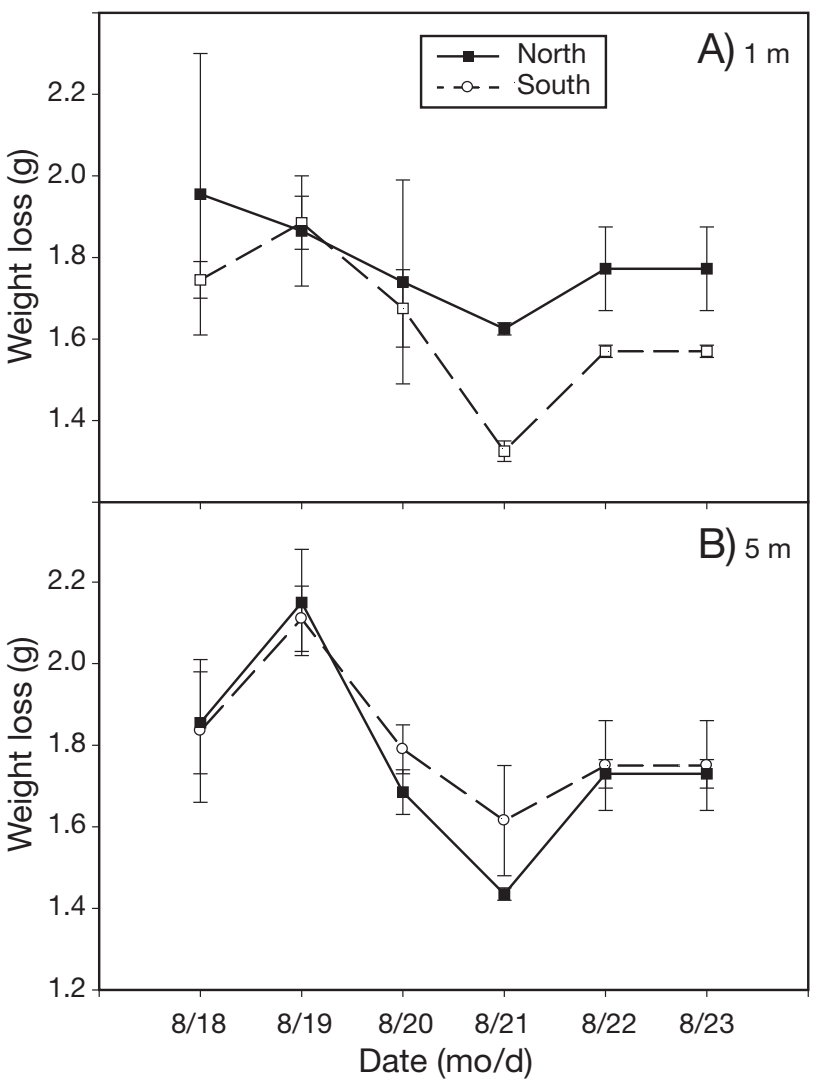

Fig. 7. Mean chalk weight loss (as an estimate of water flow) at Stn 1 at (A) $1 \mathrm{~m}$ and (B) $5 \mathrm{~m}$ moorings at north and south sites. Error bars: $\pm \mathrm{SE}$

was greater at $5 \mathrm{~m}$ depth (Table 8, Fig. 7). Stn 3 chalk block dissolution also varied temporally and was greater at the north site (Table 8, Fig. 7A). Despite the parallel changes in onshore chl $a$, concentrations varied through time between sites (Date $\times$ Site, $F_{6,28}=12.1, \mathrm{p}<0.001$ ) (Fig. 6B, Table 8). Salinity and temperature were not different between sites $\left(F_{1,14}=0, \mathrm{p}=1.00, F_{1,14}=0.07, \mathrm{p}=\right.$ 0.80) (Fig. 6C). Chalk dissolution, salinity and chl a were all positively correlated between sites (Table 7). 
Table 8. 2-way ANOVA results for Stn 1, mooring chalk dissolution at the south site (fixed factors: Date, Site), Stn 3, onshore chalk dissolution (fixed factors: Date, Depth) and chlorophyll a (fixed factors: Date, Site). ${ }^{\mathrm{a}}$ : non-normal data

\begin{tabular}{|lccccc|}
\hline Source & SS & df & MS & $F$ & $p$ \\
\hline \multicolumn{4}{l}{ Stn 1 south-mooring chalk } \\
Date & 1.54 & 4 & 0.39 & 68.6 & $<0.001$ \\
Depth & 0.06 & 1 & 0.06 & 9.90 & 0.01 \\
Date $\times$ Depth & 0.01 & 4 & 0.00 & 0.58 & 0.69 \\
Error & 0.06 & 10 & 0.01 & & \\
Stn 3-onshore chalk & & & & \\
Date & 3.68 & 8 & 0.46 & 5.43 & $<0.001$ \\
Site & 15.7 & 1 & 15.7 & 185 & $<0.001$ \\
Date $\times$ Site & 0.69 & 8 & 0.09 & 1.01 & 0.43 \\
Error & 5.84 & 69 & 0.09 & & \\
Chlorophyll & $a$ & & & & \\
Date & 335 & 6 & 55.7 & 102 & $<0.001$ \\
Site & 23.56 & 1 & 23.6 & 43.2 & $<0.001$ \\
Date $\times$ Site & 39.47 & 6 & 6.58 & 12.1 & $<0.001$ \\
Error & 15.28 & 28 & 0.55 & & \\
\hline
\end{tabular}

\section{DISCUSSION}

The combination of integrated and instantaneous sampling methods employed in the present study revealed some interesting patterns of larval abundance and settlement variability along-shore, across-shore and with depth that contribute to our understanding of temporal and spatial coherence and the appropriate methodologies to measure population replenishment processes. In the along-shore plane, 100s of $\mathrm{m}$ from shore (Stn 1, mooring settlement), settlement patterns varied, while adjacent to shore (Stn 2, instantaneous pumps) larval abundance patterns were relatively spatially coherent. As larvae were delivered to shore (Stn 3, integrated traps) this spatial coherence was maintained for barnacles, whereas mussel larval supply and both mussel and barnacle settlement varied. Temporally, onshore settlement patterns were synchronous for barnacles only (Fig. 3) and between-site variation in barnacle larval abundance and onshore supply was greater when broken down by taxon (Fig. 4). Across-shore, settlement and larval abundance patterns changed from offshore to onshore. Mussel settlement decreased and mussel and barnacle larval abundances adjacent to shore (instantaneous pumps) and onshore larval supply (integrated traps) were uncorrelated. Barnacle species composition also changed, decreasing in species diversity from adjacent to shore to onshore larval supply and settlement.
These findings suggest that each sampling methodology effectively captured different aspects of spatial and temporal variation in larval abundance, onshore supply and settlement, and were most informative when used simultaneously. The comparison of the methodologies highlights important differences between, and the advantages of, integrated versus instantaneous measurements. These differences are discussed in detail below and are briefly summarized in Table 9 .

\section{Along-shore and across-shore variability}

In the along-shore axis, for the high-frequency sampling employed in the present study, offshore mussel settlement was variable, with higher settlement at $5 \mathrm{~m}$ at the south site. Settlement offshore at $1 \mathrm{~m}$ was too low for statistical analysis and no barnacle settlement was observed on the mooring plates at either depth. The lack of barnacle settlement on open-water mooring plates has been observed in other studies (B. Grantham unpubl. data). We do not know the cause of this, but it may be due to the lack of settlement cues (i.e. conspecifics, intertidal substratum chemical cues) in the surf zone environment. In contrast, settlement on mooring plates has been observed in more sheltered bay environments (McCulloch \& Shanks 2003, Mace \& Morgan 2006a).

Prior high-frequency studies have attributed spatial variability in settlement (both mussel and barnacle) on shallow-water moorings to the movement of topographically generated fronts within a bay (McCulloch \& Shanks 2003) or position relative to the lee of a headland (Mace \& Morgan 2006a). In the present study, however, because the topography of our study site is more open and both sites were on exposed benches at the end of a headland, these explanations seem less likely to cause the observed variability. Instead, settlement may have been influenced by differences in flow

Table 9. Summary of the differences between sites in larval or settlement abundance and timing for all sample types at all stations. For abundance columns, results are from 2-way ANOVAs (Date $\times$ Site). ${ }^{* *}$ : significant interaction; ns: no significant difference; ${ }^{*}$ : significant difference. For timing columns, results are from correlation analysis, the sign denotes the direction of correlation and a repeated sign represent a significant correlation at the $5 \%$ level. Empty cells represent samples for which there were no data

\begin{tabular}{|c|c|c|c|c|}
\hline & $\begin{array}{l}\text {-Abunc } \\
\text { Barnacle }\end{array}$ & dance- & $\begin{array}{l}\text { Timin } \\
\text { Barnacle }\end{array}$ & Mussel \\
\hline \multicolumn{5}{|l|}{ Stn 1 Offshore settlement: $1 \mathrm{~m}$} \\
\hline $\begin{array}{r}\text { Stn } 2 \text { Nearshore larval abundance: } 1 \mathrm{~m} \\
\text { Nearshore larval abundance: } 5 \mathrm{~m}\end{array}$ & ns & ns & + & $\begin{array}{l}++ \\
++\end{array}$ \\
\hline $\begin{array}{l}\text { Stn } 3 \text { Onshore supply } \\
\text { Onshore settlement }\end{array}$ & $\mathrm{ns}$ & * & $\begin{array}{c}+ \\
+ \\
++\end{array}$ & ++ \\
\hline
\end{tabular}


(chalk dissolution was greater on the south mooring), competent mussel larval patchiness and, potentially, post-settlement mortality.

Although just 100 s of $\mathrm{m}$ from the shore the abundances of competent larvae were spatially variable (as shown by offshore mussel settlement above), larval distributions were relatively coherent closer to shore. Abundances of barnacle cyprids (all species) and mussels (Stn 2, instantaneous pump samples) were not different between sites 100s of $\mathrm{m}$ apart and were positively correlated. This pattern changed onshore: barnacle onshore supply was coherent among sites (i.e. no differences) and was dominated by Balanus glandula. In contrast, mussel larval supply was higher at the north site. This taxon-specific difference in onshore larval supply (despite the coherence between sites and species for the plankton pump samples) may be the result of differential delivery of competent larvae to the shore. The total number of mussel larvae (i.e. competent and precompetent) may have been similar between sites, yet different proportions of the competent larvae may have settled subtidally (or lower in the intertidal), altering the larval supply to the midintertidal where the traps were located. The low numbers of mussels settling onshore (see below) support the suggestion that largely precompetent larvae were being delivered during the study period. Alternatively, the higher mussel supply at the northern site could be due to site differences in onshore flow (the northern intertidal site had greater chalk dissolution). However, flow through the traps was most likely limited largely by the size of the opening of the 1-way valve rather than flow over the traps.

Similar to onshore larval supply, onshore settlement of mussels and barnacles was also variable. Although onshore mussel settlement was too low for statistical analysis, qualitatively, onshore mussel settlement was highly variable between dates and sites. Interestingly, high settlement offshore (on moorings) was not correlated with high onshore settlement on the same day. The peak in offshore mussel settlement (Stn 1) and nearshore larval abundance in pump samples (Stn 2) at both sites occurred one day before the peak in onshore larval abundance and settlement (Stn 3) at the south site. This is consistent with the possibility that mussel larvae were abundant in the offshore environment and had just begun to arrive onshore when they were captured in pump samples on the first day (21 August). Then, over the following day, transport that delivered larvae primarily to the south site resulted in the peak in onshore mussel settlement and larval abundance in traps detected on 22 August. The number of larvae found in onshore traps and on settlement plates is relatively consistent with observed relationships between larval abundance and settlement $\left(\sim 1\right.$ settler tuffy ${ }^{-1}$ for every 20 larvae trap ${ }^{-1}$; J. Tyburczy et al. unpubl. data). However, the peak offshore settlement (nearly 60 mussel settlers tuffy ${ }^{-1}$ ) was much higher than the subsequent onshore settlement peak of $<3$ mussels tuffy ${ }^{-1}$. One possible explanation for this is that the competent larvae detected in the offshore environment (Stn 1) may have settled subtidally, decreasing the number of competent larvae reaching the mid-shore stations, resulting in attenuated mussel abundance. Other potential explanations for this attenuation include larval mortality and limited across-shore transport. This highlights the advantage of using several sampling methodologies when interpreting findings. Having information on larval abundance, delivery and settlement provides a more comprehensive picture of how larval distributions change as they traverse through the surf zone to shore (i.e. compared to having only nearshore larval abundance or settlement data).

Barnacle cyprid settlement was also different between sites (but collectively dominated by Balanus glandula), with higher settlement at the south site. It is unlikely that the differences in barnacle settlement were caused by differential larval supply (i.e. there were no between-site differences in larval cyprid abundances in traps) or by differences in temperature and salinity. At the north site, rapid water flow may impede barnacle settlement (i.e. if flow is $>30 \mathrm{~cm} \mathrm{~s}^{-1}$ ) and/or flow speeds may be optimal for settlement (3 to $15 \mathrm{~cm} \mathrm{~s}^{-1}$ ) at the south site (Qian et al. 1999, Jonsson et al. 2004). This possibility is supported by the chalk dissolution data where dissolution was greater at the north site (Fig. 6A). The process of settlement involves cues that are likely influenced by site-specific factors such as substratum, presence of conspecifics and avoidance of competitors and/or predators (Todd 1998). Correspondingly, many studies have attributed differential settlement patterns to larval choice and behaviour (Jenkins 2005, Ladah et al. 2005). Pineda (1994) noted that spatial variation in barnacle settlement was associated with behaviour and substratum variability while temporal variation was related to the larval pool (scales of 100s of m). Our results are consistent with this suggestion; barnacle settlement was positively correlated through time (temporal coherence), yet different abundances were found at each site (spatial variation) (Pineda 1994).

This temporal coherence, but spatial variability, of barnacle settlement raises an important issue regarding the use of settlement data in studies of larval transport. Because settlement is influenced by so many processes (e.g. larval attachment, response to substratum cues, successful metamorphosis) in addition to the transport mechanisms that deliver larvae to shore, it can be potentially difficult to decipher what drives the patterns. For example, if settlement is not observed 
onshore it is difficult to determine if the lack of settlement is due to a lack of larvae or the processes that influence settlement mentioned above. This point is evident in the differences in barnacle species composition in the traps compared to the settlement plates. The settlement patterns of Balanus glandula at each site were very similar to the traps (and showed positive correlation). Although other barnacle species were observed in the traps, very few settled on the plates, suggesting that larval supply of these species to the intertidal is greater than would be assumed based on settlement collectors. Utilizing integrated onshore traps enables us to determine the level of onshore larval supply, independent of settlement, and potentially, to pinpoint the part of the life cycle most greatly influenced by transport processes (i.e. larval stages).

\section{Depth variability}

In addition to along-shore and across-shore axes, larval abundances and settlement patterns can also vary with depth, with important consequences for onshore transport. In the present study, depth distributions varied across-shore and among species. Offshore, on moorings deployed in 10 to $15 \mathrm{~m}$ water depth, mussel settlement was higher at the $5 \mathrm{~m}$ sampling depth than at the $1 \mathrm{~m}$ sampling depth. In the nearshore waters adjacent to the intertidal, larval mussels were well mixed (i.e. no differences in plankton mussel abundances with depth). This difference in depth stratification between nearshore and onshore may be the result of differential distribution of life cycle stages, competent mussel larvae being found deeper offshore and moving towards the surface as they get closer to the intertidal, mussels becoming well mixed in the surf zone or because we cannot differentiate competent mussel larvae in the pump samples (i.e. pump samples include both competent and precompetent larvae). Stratification of mussel larvae has been observed elsewhere (White Sea, Russia; Dobretsov \& Miron 2001) with mussel Mytilus edulis larvae generally being found at $4.5 \mathrm{~m}$ until settlement when they were found closer to the surface. Other studies of $M$. edulis have found higher abundances of competent mussel larvae deeper in the water column (Thorson 1950), which appears to be the case for mussels 100s of $\mathrm{m}$ from shore in Oregon (present study), New Zealand (Rilov et al. 2008) and South Africa (M. Pfaff pers. comm.).

Unlike mussel larvae, larval barnacle cyprids were depth stratified in the nearshore waters adjacent to the rocks and were more abundant at $1 \mathrm{~m}$ depth. Vertical position in the water column can be important for larval transport, particularly on the Oregon coast where surface and bottom currents are often moving in opposing directions due to seasonal upwelling (Kirincich et al. 2005). The abundance of barnacles in surface waters suggests that very nearshore larvae would be transported onshore during downwelling conditions, which has been observed for invertebrates (including barnacles) in previous studies on the coasts of Oregon (Dudas et al. 2009), California (Farrell et al. 1991, Wing et al. 1995a,b) and Japan (Noda 2004). However, if barnacle depth distribution changes farther away from shore (i.e. barnacles are found deeper), they may be transported onshore during upwelling conditions (Grantham 1997, Mace \& Morgan 2006a, Mace \& Morgan 2006b). Barnacle depth distribution may also be dependent on species. Grosberg (1982) found Balanus glandula predominantly in surface waters while $B$. crenatus was found deeper. Similarly, in our analyses for each barnacle species, B. glandula had higher abundances at $1 \mathrm{~m}$ while $B$. crenatus showed no depth stratification.

\section{Instantaneous versus integrated larval sampling}

The use of instantaneous pump sampling methodology enabled the observation of these species-specific depth distributions simultaneously with integrated onshore larval supply and settlement data. Each methodology has its own unique attributes and advantages. For example, both instantaneous (pumps) and integrated samples (plankton traps) were able to capture temporal and spatial variation in larval abundances. Onshore barnacle supply and species composition in the traps were more strongly correlated with settlement than with plankton barnacle abundance in the pump samples. This was not surprising given that larval temporal variation can be high and pump samples may vary greatly depending on when they are taken. Traps, by sampling over a longer period, integrate temporal variation over the same deployment interval as settlement collectors. Also, each sample type may be sampling different water masses and larval patches. The pump samples measure larval concentrations adjacent to the shore while the trap samples measure the water that washes directly over the intertidal zone. Larval concentrations may change between the time when a pump sample is taken and when the water flows over the intertidal. During this time some larvae may settle, die or be transported on-, off- or alongshore. Thus the concentration of larvae delivered to the mid-intertidal may be very different from that sampled by the pump. This point is highlighted by differences in barnacle species composition between sampling methods. Barnacle species composition was highly variable in pump samples, while trap and plate samples were dominated by Balanus glandula. The 
differences in species composition are likely the result of species-specific intertidal zonation. The pump samples caught species that settle both intertidally and subtidally. For example, B. crenatus and B. nubilus are primarily subtidal while Chthamalus dalli, B. glandula and Pollicipes polymerus are all common in the intertidal (Kozloff 1993). Correspondingly, the traps had lower numbers of $B$. crenatus than the pump samples.

These species-habitat differences may contribute to the stronger correlations of trap data with barnacle settlement on the plates, which also provide a timeintegrated sample. Our findings are in agreement with a similar study that examined onshore recruitment and larval abundance with a tube plankton trap, showing higher correlations between plankton trap samples and onshore settlement versus pump samples (Gaines \& Bertness 1993). Correlations between larval pump samples and onshore settlement are variable among studies; some have found relatively strong correlations (Minchinton \& Scheibling 1991, Miron et al. 1995) while others have found very weak correlations or none at all (Gaines \& Bertness 1993, Miron et al. 1995, Olivier et al. 2000). Our results are consistent with studies that found that integrated sampling is a better predictor of intertidal settlement.

Our findings highlight the importance of matching the appropriate sampling methodology to the research question. If the research is focused on assessing the availability of larvae for settlement onshore, instantaneous pump samples would be appropriate. On the other hand, if one is interested in assessing the delivery of larvae to the shore over a given time interval, integrated larval traps would be more suitable. Both methods are useful for examining larval distributions across-shore as larvae traverse the last $100 \mathrm{~s}$ of $\mathrm{m}$ towards the intertidal.

\section{CONCLUSIONS}

In the present study we demonstrated how invertebrate settlement and larval distributions changed as larvae move across the final 100s of m towards shore. High settlement nearshore and/or high onshore larval supply did not necessarily translate into high onshore settlement. Patterns of settlement and larval distributions along-shore, across-shore and with depth were also taxon- and species-dependent. Both instantaneous and integrated sampling methodologies were able to capture variation in larval abundance, but each method sampled a different part of the water column and potentially a different part of the larval life history. Instantaneous samples capture larvae that may or may not be delivered to shore and measure concentration only, while integrated samples measure the flux of lar- vae that are supplied or delivered to the rocky intertidal zone and measure flux. Depending on the research questions being asked, instantaneous or integrated sampling methodologies may be used individually or in concert. Both provide insight into the interactions between larvae, oceanography and replenishment of intertidal populations, and the present study highlights the benefits of using both approaches. In terms of sampling methodology, the traps provide a distinct logistical advantage over instantaneous pump or net samples because several sites can be sampled simultaneously over a longer time period.

Understanding the connections between plankton larval abundance, onshore supply and settlement in the context of local and regional oceanography will provide valuable information on larval dispersal and potential connectivity between populations. Having now established both the methodologies to sample this highly exposed environment and the patterns of variability at scales of 100 s of $\mathrm{m}$, our next step is to investigate the patterns in larval supply and settlement at 1000 s of $\mathrm{m}$ in relation to potential oceanographic transport mechanisms. This research is currently being conducted along the coasts of Oregon and California.

Acknowledgements. This paper is contribution no. 340 from the Partnership for Interdisciplinary Studies of Coastal Oceans (PISCO), for which core funding is provided jointly by the Gordon and Betty Moore and the David and Lucile Packard Foundations. Additional funding was provided by the Andrew W. Mellon Foundation, the Wayne and Gladys Valley Foundation and the Bob and Betty Lundeen Marine Biology fund at Oregon State University. We thank R. Driscoll and R. Hilgris for assistance in the field and lab and trap design; M. Robart, C. and S. Holmes for their assistance on the boat; D. and R. McCoy, K. Milligan, J. Lubchenco and B. Martin for field assistance; A. Rogers, J. Ahrens and M. Packard for lab assistance; and G. Williams for helping with trap development.

\section{LITERATURE CITED}

Bakun A, Weeks SJ (2004) Greenhouse gas buildup, sardines, submarine eruptions and the possibility of abrupt degradation of intense marine upwelling ecosystems. Ecol Lett 7:1015-1023

Castilla JC, Varas MA (1998) A plankton trap for exposed rocky intertidal shores. Mar Ecol Prog Ser 175:299-305

Castilla JC, Pacheco C, Varas M, Ortiz V (2001) The rocky intertidal plankton trap RIPT2: a modified device. Sarsia 86:37-41

Dobretsov SV, Miron G (2001) Larval and post-larval vertical distribution of the mussel Mytilus edulis in the White Sea. Mar Ecol Prog Ser 218:179-187

> Dudas SE, Grantham BA, Kirincich AR, Menge BA, Lubchenco J, Barth JA (2009) Current reversals as determinants of intertidal recruitment on the central Oregon coast. ICES J Mar Sci 66:396-407

Farrell TM, Bracher D, Roughgarden J (1991) Cross-shelf transport causes recruitment to intertidal populations in central California. Limnol Oceanogr 36:279-288 
Gaines SD, Bertness M (1993) The dynamics of juvenile dispersal: why field ecologists must integrate. Ecology 74 : 2430-2435

Gaines S, Roughgarden J (1985) Spatial variation in larval concentrations as a cause of spatial variation in settlement for the barnacle, Balanus glandula. Oecologia 67:267-272

Grantham BA (1997) Coastal upwelling, larval recruitment, and the dynamics of upper intertidal barnacle communities. PhD dissertation, Stanford University, Palo Alto, CA

Grosberg RK (1982) Intertidal zonation of barnacles: the influence of planktonic zonation of larvae on vertical distribution of adults. Ecology 63:894-899

Guichard F, Bourget E (1998) Topographic heterogeneity, hydrodynamics, and benthic community structure: a scale-dependent cascade. Mar Ecol Prog Ser 171:59-70

> Hunt HL, Scheibling RE (1996) Physical and biological factors influencing mussel (Mytilus trossulus, M. edulis) settlement on a wave-exposed rocky shore. Mar Ecol Prog Ser 142:135-145

Jenkins SR (2005) Larval habitat selection, not larval supply, determines settlement patterns and adult distribution in two chthamalid barnacles. J Anim Ecol 74:893-904

> Jonsson PR, Berntsson KM, Larsson AI (2004) Linking larval supply to recruitment: flow-mediated control of initial adhesion of barnacle larvae. Ecology 85:2850-2859

Kirincich AR, Barth JA, Grantham BA, Menge BA, Lubchenco J (2005) Wind-driven inner-shelf circulation off central Oregon during summer. J Geophys Res 110:C10S03, doi: 10.1029/2004JC002611

Kozloff EN (1993) Seashore life of the Northern Pacific Coast: an illustrated guide to Northern California, Oregon, Washington and British Columbia. University of Washington Press, Seattle, WA

Ladah LB, Tapia FJ, Pineda J, Lopez M (2005) Spatially heterogeneous, synchronous settlement of Chthamalus spp. larvae in northern Baja California. Mar Ecol Prog Ser 302: 177-185

Leslie HM, McLeod KL (2007) Confronting the challenges of implementing marine ecosystem-based management. Front Ecol Environ 5:540-548

> Mace AJ, Morgan SG (2006a) Biological and physical coupling in the lee of a small headland: contrasting transport mechanisms for crab larvae in an upwelling region. Mar Ecol Prog Ser 324:185-196

Mace AJ, Morgan SG (2006b) Larval accumulation in the lee of a small headland: implications for the design of marine reserves. Mar Ecol Prog Ser 318:19-29

McCulloch A, Shanks AL (2003) Topographically generated fronts, very nearshore oceanography and the distribution and settlement of mussel larvae and barnacle cyprids. J Plankton Res 25:1427-1439

Menge BA, Berlow EL, Blanchette CA, Navarrete SA, Yamada SB (1994) The keystone species concept: variation in interaction strength in a rocky intertidal habitat. Ecol Monogr 64:249-286

Minchinton TE, Scheibling RE (1991) The influence of larval supply and settlement on the population structure of barnacles. Ecology 72:1867-1879

Miron G, Boudreau B, Bourget E (1995) Use of larval supply in benthic ecology: testing correlations between larval supply and larval settlement. Mar Ecol Prog Ser 124:301-305

Noda T (2004) Large-scale variability in recruitment of the barnacle Semibalanus cariosus: its cause and effects on

Editorial responsibility: Jon Hare,

Narragansett, Rhode Island, USA the population density and predator. Mar Ecol Prog Ser 278:241-252

Olivier F, Tremblay R, Bourget E, Rittschof D (2000) Barnacle settlement: field experiments on the influence of larval supply, tidal level, biofilm quality and age on Balanus amphitrite cyprids. Mar Ecol Prog Ser 199:185-204

> Pineda J (1994) Spatial and temporal patterns in barnacle settlement rate along a southern California rocky shore. Mar Ecol Prog Ser 107:125-138

Pineda J (2000) Linking larval settlement to larval transport: assumptions, potentials, and pitfalls. Oceanogr East Pac 1: 84-105

Porter ET, Sanford LP, Suttles SE (2000) Gypsum dissolution is not a universal integrator of 'water motion'. Limnol Oceanogr 45:145-158

- Qian PY, Rittschof D, Sreedhar B, Chia FS (1999) Macrofouling in unidirectional flow: miniature pipes as experimental models for studying the effects of hydrodynamics on invertebrate larval settlement. Mar Ecol Prog Ser 191:141-151

Rilov G, Dudas SE, Menge BA, Grantham BA, Lubchenco J, Schiel DR (2008) The surf zone: A semi-permeable barrier to onshore recruitment of invertebrate larvae? J Exp Mar Biol Ecol 361:59-74

Thorson G (1950) Reproductive and larval ecology of marine bottom invertebrates. Biol Rev Camb Philos Soc 25:1-45

Todd CD (1998) Larval supply and recruitment of benthic invertebrates: Do larvae always disperse as much as we believe? Hydrobiologia 375-376:1-21

> Todd CD (2003) Assessment of a trap for measuring larval supply of intertidal barnacles on wave-swept, semiexposed shores. J Exp Mar Biol Ecol 290:247-269

> Todd CD, Phelan PJC, Weinmann BE, Gude AR and others (2006) Improvements to a passive trap for quantifying barnacle larval supply to semi-exposed rocky shores. J Exp Mar Biol Ecol 332:135-150

Underwood AJ (1997) Experiments in ecology. Cambridge University Press, Cambridge

Underwood AJ, Denley J (1984) Paradigms, explanations and generalizations in models for the structure of intertidal communities on rocky shores. In: Strong DR, Simberloff D, Abele LG, Thistle AB (eds) Ecological communities: conceptual issues and the evidence. Princeton University Press, Princeton, NJ

Vecchi GA, Soden BJ, Wittenberg AT, Held IM, Leetmaa A, Harrison MJ (2006) Weakening of tropical Pacific atmospheric circulation due to anthropogenic forcing. Nature 441:73-76

Welschmeyer NA (1994) Fluorometric analysis of chlorophyll $a$ in the presence of chlorophyll $b$ and pheopigments. Limnol Oceanogr 39:1985-1992

Wing SR, Botsford LW, Largier JL, Morgan LE (1995a) Spatial structure of relaxation events and crab settlement in the northern California upwelling system. Mar Ecol Prog Ser 128:199-211

Wing SR, Largier JL, Botsford LW, Quinn JF (1995b) Settlement and transport of benthic invertebrates in an intermittent upwelling region. Limnol Oceanogr 40:316-329

Yan Y, Chan BKK, Williams G (2004) An improved and simplified trap for quantifying the distribution and supply of planktonic larvae to rocky shores. J Plankton Res 26: $247-253$

Yund PO, Gaines SD, Bertness M (1991) Cylindrical tube traps for larval sampling. Limnol Oceanogr 36:1167-1177

Submitted: February 15, 2008; Accepted: May 1, 2009

Proofs received from author(s): July 6, 2009 